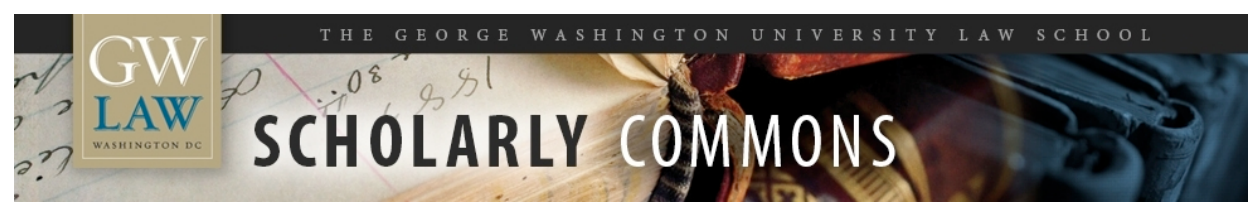

\title{
Thinking Race, Making Nation (reviewing Glenn C. Loury, The Anatomy of Racial Inequality)
}

Christopher A. Bracey

George Washington University Law School, cbracey@law.gwu.edu

Follow this and additional works at: https://scholarship.law.gwu.edu/faculty_publications

Part of the Law Commons

\section{Recommended Citation}

Northwestern University Law Review, Vol. 97, 2003

This Book Review is brought to you for free and open access by the Faculty Scholarship at Scholarly Commons. It has been accepted for inclusion in GW Law Faculty Publications \& Other Works by an authorized administrator of Scholarly Commons. For more information, please contact spagel@law.gwu.edu. 


\section{Review Essay}

\section{THINKING RACE, MAKING NATION}

reviewing

THE ANATOMY OF RACIAL INEQUALITY

By Glenn C. Loury. Harvard University Press, 2002.

Christopher A. Bracey*

[T]he real inequality that is produced by fortune or by law is always succeeded by an imaginary inequality that is implanted in the manners of people.

- Alexis de Tocqueville ${ }^{1}$

\section{INTRODUCTION}

We live in a race-conscious culture. As Americans, we are a nation of people who self-consciously chose to adopt a vision of society that embraced lofty ideals of individual freedom and democracy along with powerful mechanisms for devastating racial oppression. ${ }^{2}$ Our history is replete

\footnotetext{
* Associate Professor of Law, Washington University School of Law. I thank my research assistants Sarah Burnett and Lise Byars for their superb effort on this project. Also, I want to extend a special thank you to my colleagues Troy Paredes and F. Scott Kieff for multiple thoughtful discussions of the ideas and issues contained in this essay.

1 AleXis de Tocqueville, Democracy IN AMERICA 357 (Everyman's Lib. ed. 1994) (1835).

${ }^{2}$ Western-style racism and race consciousness are truly distinctive when viewed against the backdrop of the global history of racism precisely because each developed within an overarching cultural mindset premised upon human equality. See GEORGE M. Frederickson, RACISM: A SHORT History 12 (2002) ("It is uniquely in the West that we find the dialectical interaction between a premise of equality and an intense prejudice toward certain groups that would seem to be a precondition for the full flowering of racism as an ideology or worldview.").

The United States Constitution itself embodies a powerful contradiction - a guarantee of individual freedom for all, and an explicit endorsement of Negro slavery. Compare U.S. CONST. pmbl. ("We the people of the United States, in order to ... secure the blessings of liberty to ourselves and our posterity do ordain and establish this Constitution ....."), with U.S. ConsT. art. I, § 2, cl. 3 (counting Negro slaves as three-fifths of one person for political representation purposes), and U.S. CONST. art I, § 9, cl. 1 (allowing for the importation and federal taxing of slave labor until the 1808), and U.S. CONST. art. IV, $\S 2$, cl. 3 (creating a constitutional right to the return of fugitive slaves), and U.S. CONST. art. V (prohibiting amendment of the slave importation and taxation provision of the Constitution prior to 1808). Although the words slave and slavery are studiously excluded from the Constitution, I think former president John Quincy Adams put it best when he remarked that "circumlocutions are the fig
} 
with instances of differential treatment on account of race-slavery being only the most egregious example ${ }^{3}$ - that achieved the desired effect of generating remarkable disparities in socioeconomic well-being among individuals and between different racial groups. ${ }^{4}$ Such disparities are not simply historical artifacts. They are facts of the contemporary American racial landscape as well. ${ }^{5}$ Racial disparity in socioeconomic well-being has always been, and continues to be, a central feature of American life.

This is not to suggest that race, as embedded in American cultural consciousness, has a fixed meaning. To the contrary, it is the fluidity of racethe ability to transform from the biological to the ideological to the metaphysical - that accounts for its longevity in our national character. Confusion (or perhaps lack of consensus) regarding the meaning and significance of racial difference, I believe, has led to a surprising lack of sensitivity on the part of the American public when it comes to racial disparities. Evidence of racial disparity in health, wealth, and society is rarely met with outrage. ${ }^{6}$ Yet each of us, through the day-to-day observations that comprise

leaves under which these parts of the body politic are decently concealed." JOHN QUINCY ADAMS, ARgument of John Quincy AdAMs, BEFore THE SuPREME COURT of THE United STATES, IN THE Case of the United States, Appellants, vs. Cinque, and Others, Africans, Captured in the SCHOONER AMISTAD (1969).

${ }^{3}$ Other historic examples that further illustrate this contradiction include: Federal Indian removal policy, see The Indian Removal Act of 1830, ch. 148, 4 Stat. 411 (1830), prohibitions on the naturalization of non-whites, see Uniform Naturalization Act of 1790, ch. 3, 1 Stat. 103 (1790) (restricting naturalization to "free White persons"), curtailment of rights of Asian immigrants, see Chinese Exclusion Act of 1882, ch. 220, 23 Stat. 115 (1882) (barring entry of Chinese laborers into the United States for ten years); Scott Act of 1888, ch. 1064, 25 Stat. 504 (1888) (prohibiting Chinese resident aliens who traveled between China and the United States from reentering the United States), and Japanese American internment during World War II, see generally ERIC YAMAMOTO ET AL., RACE, RIGHTS AND REPARATION: LAW AND THE JAPANESE AMERICAN INTERNMENT (2001).

${ }^{4}$ Human relations always take place against the backdrop of the relative power possessed by each person. See MAX Weber, BASIC CONCEPTS IN SOCIOlOGY 117 (H.P. Secher trans., 1962) (describing "power" in social settings as "that opportunity existing within a social relationship which permits one to carry out one's will even against resistance and regardless of the basis on which this opportunity rests"). Slavery represents the ultimate expression of such power-absolute power for the master and absolute powerlessness for the slave-and a most obvious means of imposing social, economic, and cultural isolation. See Orlando Patterson, Slavery and Social Death: A Comparative Study 182, 183 (1982).

${ }^{5}$ For a discussion of discrimination in retail purchases, see Ian Ayres, Further Evidence of Discrimination in New Car Negotiations and Estimates of Its Cause, 94 MicH. L. REV. 109, 116 (1995) (finding that black males received final offers that were, on average, $\$ 1,132$ higher than those offered to white males); Ian Ayres, Fair Driving: Gender and Race Discrimination in Retail Car Negotiations, 104 HARV. L. REV. 817 (1991) (reporting similar results using a smaller sample of testers). For a discussion of mortgage credit discrimination or "redlining," see DOUGLAS S. MASSEY \& NANCY A. Denton, American Apartheid: Segregation and the Making of the Underclass 50-57, 10509 (1993); Keith N. Hylton \& Vincent D. Rougeau, Lending Discrimination: Economic Theory, Econometric Evidence, and the Community Reinvestment Act, 85 GEO. L.J. 237, 241 (1996) (citing GeORge J. Benston et AL., An EMPIRICAL Study OF Mortgage Redlining 1-33 (1978) (summarizing a number of empirical studies confirming the existence of redlining in various communities)).

${ }^{6}$ Perhaps one of the most disturbing areas in which we witness a conspicuous absence of outrage at 
our life experience, comes to understand, to a greater or lesser extent, the vital importance of race in shaping our individual destinies. Whether we experience racial inequality through the prism of privilege or poverty, it is difficult to ignore this crucial aspect of our existence.

Of course, we each choose how we come to terms with racial inequality, how we rationalize, compartmentalize, or explain this phenomenon, and how we integrate our "raced" existence into our personal view of the world. For nearly three generations, we have undertaken a largely sustained collective effort to eliminate racial discrimination in American society. ${ }^{7}$ For some, the persistence of chronic racial inequality in the face of sustained efforts to ameliorate racial discrimination confirms deeply held suspicions regarding the intellectual, cultural, or economic capacity of African Americans. ${ }^{8}$ For others, the persistence of racial disparity highlights the limits of the prevailing approach to antidiscrimination law ${ }^{9}$ and makes the

racial disparity is in the context of the ever-increasing prison population in the United States. Critics of such disparity, such as Marc Mauer and Michael Tonry, struggle to shake public indifference on this issue. See Marc Mauer, Race To Incarcerate (1999); Michael Tonry, Malign Neglect: Race, CRIME, AND PUNISHMENT IN AMERICA (1995). Indeed, Mauer wonders explicitly if society would express similar acceptance and complacency if most prisoners were white, instead of half the prison population being black, and another seventeen percent Latino. Mauer, supra, at 12, 118.

7 See generally Aldon D. Morris, The Origins of the Civil Rights Movement: Black COMMUNITIES ORGANIZING FOR CHANGE (1984). For an account of litigation that secured civil rights reforms between 1936 and 1961, see MARK V. Tushnet, MAKING Civil Rights LAW: ThurgOOD MARSHALl AND THE SUPREME COURT, 1936-1961 (1994). For an intriguing history of trials and tribulations of the NAACP Legal Defense Fund, see Jack GreEnberg, Crusaders in the Courts: How A Dedicated Band of LAWYers Fought For the Civil Rights Revolution (1994). For an account of the civil rights movement viewed through the narrative of Martin Luther King, Jr.'s life, see TAYLOR Branch, PARTing the Waters: America in the King Years, 1954-63, at 212 (1988). For a general overview of events and litigation immediately following the Supreme Court's decision in Brown $v$. Board of Education, see Richard Kluger, Simple Justice: THE History of BROWN V. BOARD OF EDUCATION AND BLACK AMERICA'S STRUGGLE FOR EQUALITY 748-78 (1975).

${ }^{8}$ See, e.g., Richard J. Herrnstein \& Charles Murray, The Bell Curve: Intelligence and Class StRUCTURE IN AMERICAN LiFe (1994) (purporting to document differences between races in measured intelligence and positing that such differences are genetic in origin); DINESH D'SOUZA, THE END OF RACISM: PRINCIPLES FOR A MULTIRACIAL SOCIETY (1995) (arguing that African Americans, as a group, are culturally inferior to whites); John MCWhorter, Losing the RACE: SELF-SABOtage IN BLACK AMERICA (2000) (arguing that deficiencies in African American socio-economic well-being are attributable to three self-imposed features of African American society: a desire to play the perpetual role of society's victim, a love for separatism, and a propensity to reward anti-intellectual achievement).

9 The antidiscrimination principle animates our prevailing approach to eliminating racial discrimination in American society. The antidiscrimination principle is premised on the basic idea that law should not classify or treat persons differently simply because those persons belong to a different race, and that we should be suspicious of any attempt to do so. Much of modern civil rights law and doctrine is premised upon this basic notion. See Paul Brest, Forward: In Defense of the Antidiscrimination Principle, 90 HARV. L. REV. 1, 1 (1976) (noting that "Congress read the antidiscrimination principle into the thirteenth amendment; and the Supreme Court has construed the amorphous language of the equal protection clause of the fourteenth amendment to hold that racial classifications are 'constitutionally suspect' and subject to "the most rigid scrutiny" and observing that "[t]he antidiscrimination principle lies at the core of most state and federal civil rights legislation, including the Civil Rights Act of 1964, the Voting Rights Act of 1965, and the Fair Housing Act of 1968" (footnotes omitted)). As a general matter, one 
case for greater intervention. ${ }^{10}$

Glenn C. Loury's The Anatomy of Racial Inequality is a thoroughgoing attempt to ascertain the root causes of racial inequality and provide insight into the thought process that causes us to view racial disparity with complacency and indifference. However, Loury's project is not merely descriptive. How we choose to comprehend racial inequality has tremendous normative implications for how we shape our national identity. Thus, Loury's structural account of racial inequality provides the staging ground

must prove discriminatory intent in order to establish that violation of antidiscrmination law has occurred. See, e.g., Personnel Adm'r v. Feeney, 442 U.S. 256, 278-80 (1979) (holding that incidental effect on a protected group is insufficient to demonstrate discriminatory purpose); Vill. of Arlington Heights v. Metropolitan Hous. Dev. Corp., 429 U.S. 252, 264-68 (1977) (holding that proof of racially discriminatory intent is necessary to establish a violation of the Equal Protection Clause); Washington v. Davis, 426 U.S. 229, 248-52 (1976) (rejecting a disparate impact theory in an equal protection claim). For an interesting critique of this position, see Alan Freeman, Legitimating Racial Discrimination Through Antidiscrimination Law: A Critical Review of Supreme Court Doctrine, 62 MinN. L. Rev. 1049 (1978) (arguing that the intent-impact controversy is one element of a more general ideological struggle between "victim" and "perpetrator" perspectives within antidiscrimination law). Similarly, the federal courts have construed the antidiscrimination principle as hostile toward affirmative action measures and other arguably benign racial classifications. See Adarand Constructors, Inc. v. Pena, 515 U.S. 200 (1995) (declaring unconstitutional a federal program designed to enhance participation of minorityowned construction firms in government contracting); Wessmann v. Gittens, 160 F.3d 790, 798 (1st Cir. 1998) (rejecting Boston Latin School's affirmative action plan for only considering race and not other dimensions of diversity); Hopwood v. Texas, 78 F.3d 932 (5th Cir. 1996) (holding that admissions plan considering only blacks and Mexican-Americans, but not other racial groups or nonracial dimensions of diversity fails narrow tailoring); Johnson v. Regents of Univ. of Ga., 106 F. Supp. 2d 1362, 1369 (S.D. Ga. 2000) (same), aff'd, 263 F.3d 1234 (11th Cir. 2001) (finding that "diversity" in higher education cannot constitute a constitutionally compelling government interest); Grutter v. Bollinger, 137 F. Supp. 2d 821, 847 (E.D. Mich. 2001) (same).

${ }^{10}$ See Kimberlé W. Crenshaw, Race, Reform, and Retrenchment: Transformation and Legitimation in Antidiscrimination Law, 101 HARV. L. REV. 1331, 1376-81 (1988) (arguing that antidiscrimination law has largely succeeded in eliminating symbolic manifestations of racial oppression but has allowed the perpetuation of material subordination of people of color); DERRICK BELL, AND WE ARE NOT SAVED: The Elusive Quest FOR RACIAL Justice 3 (1987) ("With the realization that the salvation of racial equality has eluded us again, questions arise from the ashes of our expectations: How have we failed - and why? What does this failure mean - for black people and for whites? Where do we go from here? Should we redirect the cause for racial justice?"); Linda S. Greene, Race in the 21st Century: Equality Through Law?, 64 TUL. L. REv. 1515, 1517 (1990) ("The civil rights decisions of the 1989 Term force us to refocus on a question presented time and time again, before and after Dred Scott: whether meaningful equality can be obtained for African Americans through law.").

This line of argument also arises within the context of reparations for slavery. The scholarly and popular literature on reparations has grown tremendously in the decades following the publication of Boris I. Bittker's The Case for Black Reparations in 1973. See, e.g., Randall Robinson, The DebT: What America Owes to Blacks (2000); Joe R. Feagin, Racist America: Roots, Current Realities, and Future Reparations (2000); George Schedler, Racist Symbols and Reparations: Philosophical Reflections on Vestiges of the American Civil War (1998); DERRICK BEll, RACE, RACISM, AND AMERICAN LAW 54-55 (3d ed. 1992); MARY FranCES BERRY \& John W. Blassingame, Long Memory: THE Black EXPERIENCE IN AMERICA 405-06 (1982); see also Robert Westley, Many Billions Gone: Is It Time To Reconsider the Case for Black Reparations?, 40 B.C. L. REV. 429 (1998); Vincene Verdun, If the Shoe Fits, Wear It: An Analysis of Reparations to African Americans, 67 TUL. L. REV. 597 (1993). 
from which he launches a deep critique of prevailing views on American race relations. "The 'conservative line' on race in America today is simplistic," writes Loury. ${ }^{11}$ Racial inequity is not the product of some inherent deficiency in the minds and hearts of African Americans. Rather, it is a social pathology "deeply rooted in American history"-a pathology that "evolved in tandem with American political and economic institutions, and with cultural practices that supported and legitimated those institutions . . . that were often deeply biased against blacks." 12 Loury rejects the complacency evinced by this conservative policy of indifference toward racial disparities, and declares emphatically that racial inequality is "an American tragedy [and] a national, not merely a communal disgrace."13

The Anatomy of Racial Inequality is Loury's attempt to unveil the architecture that sustains racial inequality in an effort to define a normative orientation for racial policy in the years to come. His argument proceeds in four discrete phases. First, Loury argues that race is a powerfully important social convention, though it has no real scientific basis. ${ }^{14}$ The social convention of race, according to Loury, was historically critical to the dispensation of rewards and privileges in the United States.

In the second phase of his argument, Loury attempts to explain the salience of race-based thinking in the minds of white Americans. Loury maintains that the roots of race-based thinking lie in racial stereotypes. Whites assign qualities and characteristics to African Americans and then act in accordance with these stereotypes. Because whites structure institutions and arrangements in a manner that is consistent with and predictive of these stereotypes, Loury maintains that the stereotyped group often responds in ways that demonstrate or reflect these same qualities and characteristics. In other words, institutions and customs that are designed with stereotypes "in mind," so to speak, often generate behavior and structural outcomes that are consistent with the stereotypes.

This self-confirming "feedback loop" that sustains informal anti-black bias could be easily overcome, according to Loury, simply by viewing targets of informal discrimination as individuals of equal humanity and not as the walking embodiment of a collectively stereotyped racial identity. But as Loury perceptively notes, "people do not freely give the presumption of equal humanity." 15 Thus, in the third phase of his argument, Loury seeks to explain why stereotypes that sustain racial inequality are so intractable. The great barrier to the bestowal of equal humanity, says Loury, is the powerful role that racial stigma plays in shaping deeply held beliefs and attitudes. ${ }^{16}$

11 Glenn C. Loury, The ANAtomy of RaCial InEQuality 105 (2002).

12 Id.

13 Id.

${ }^{14}$ Id. at $20-23$.

${ }^{15}$ Id. at 87.

${ }^{16} \mathrm{Id}$. at 88 . 
Racial stigma, according to Loury, is not so much about casual observations of blacks as it is about characteristics about the inherent nature of African Americans - about who, at the deepest level, they are understood to be. American blacks, according to Loury, have suffered the most from stigmatization as a result of the historical taint of slavery. Blacks, dishonored as a race by slavery, possess what he calls a "spoiled identity." 17 It is the lingering effects of this spoiled identity that make it difficult for whites today to view blacks as individuals like themselves. This spoiled identity, reinforced by social structures, explains why African Americans, despite advances, are still at the bottom on many social and economic indices, and why whites are largely indifferent to evidence of racial disparity.

Each of the foregoing arguments leads Loury to the conclusion that traditional individual-based, process-oriented colorblind liberalism will not solve the problem. Overt racial discrimination in formal social interactions - such as discrimination in the job market - is no longer the chief obstacle to overcoming racial inequality. Rather, it is "discrimination in contact," which Loury describes as informal and entirely legal patterns of socializing and networking that tend to exclude blacks, that most powerfully reinforce racial inequality in the modern era. Because the absence of overt discrimination creates the illusion of equality, Loury maintains that it is "rational" but incorrect for the informal discriminator to conclude that evidence of racial disparity is simply a reflection of the natural order of things. Racial stigma and the practice of informal racial discrimination, then, and not overt racial discrimination, are the root causes of African American underdevelopment and the perpetuation of racial inequality.

Hence, the challenge to racial inequality must focus on the eradication of racial stigma and the assertion and acknowledgment of the essential humanity of blacks. This task, according to Loury, cannot be undertaken with colorblind indifference. To the contrary, Loury concludes that the promise of fairness, individual freedom, and dignity will remain unfulfilled without some form of intervention based upon race. Public policy must promote substantive racial egalitarianism that is directed squarely at remedying racial disparities rather than procedural equality designed to address concrete instances of "provable" racial discrimination.

Loury has presented a powerfully written and tightly argued book that could very well serve as an intelligent manifesto (although, given its pronounced moralistic tone, I suspect Loury would be more comfortable with "sermon" as a descriptor) for future writings on the concept of racial inequality. It is an interdisciplinary text that is rich with transformative possibilities. Loury's book walks a difficult line: on one side is the hope and optimism of being able to make sense of things descriptively and normatively. On the other side is the critical impulse of nihilism-one that risks, but does not indulge, the impulse to collapse into despair and passivity,

${ }^{17}$ Id. at $65-69$. 
with a loss of faith in the human capacity to overcome the taint of racial stigma and racial disparities that ensue.

In a very real sense, Loury's free and extended meditation on racial inequality and the prospects of racial reform provides us with an insightful theoretical and discursive structure through which we can engage the struggle for racial justice anew. In Part II of this Review Essay, I examine and critique the major arguments presented in the book. In Part III, I conclude by offering a few thoughts on what Loury's analysis may mean for the future of American race relations.

\section{THE LOURY THESIS OF RACIAL INEQUALITY}

\section{A. Getting Sight of Racial Disparity}

A crucial first step in addressing the problem of racial inequality is to understand and appreciate the scope and magnitude of the problem. For Loury, the problem is clear:

Nearly a century and a half after the destruction of the institution of slavery, and a half-century past the dawn of the civil rights movement, social life in the United States continues to be characterized by significant racial stratification.... Indeed, over the past quarter century the disadvantages of blacks... [have] remained unchanged, or, in some instances, [have] even worsened. $^{18}$

In support of this proposition, Loury has collected data on various indicia of socioeconomic well-being - including wages, unemployment rates, wealth levels, standardized test scores, incarceration rates, and mortality statistics - that "reveal substantial racial disparities."19

Interestingly, these data are neither presented nor discussed at length in the text. Instead, the data are consigned to an extended appendix and presented in crude tabular form. This style of presentation immediately triggers two thoughts in the mind of the skeptical reader. First, how much racial disparity is really out there? Second, is the evidence of disparity sufficient to warrant an extended meditation on its cause? Loury asserts that "we have a problem; it will be with us for a while; and it behooves us to think hard about what can and should be done." 20 But given the minimal discussion of the nature and extent of racial inequality provided thus far, what are we to make of this loose, moralistic claim? What reason do we have to shake off the complacency and indifference that Loury says have characterized our response in the past?

Fortunately for Loury, these data provide strong support for his otherwise gauzy proposition. African Americans with the same level of educa-

\footnotetext{
18 Id. at 3-4.

19 Id. at 4.

${ }^{20} I d$.
} 
tion as whites continue to earn substantially less. ${ }^{21}$ Blacks continue to occupy proportionally fewer managerial positions and proportionally greater service and unskilled labor positions. ${ }^{22}$ Median family income for African Americans is roughly two-thirds that of whites. ${ }^{23}$ Black youth continue to lag behind whites in performance on standardized tests for mathematics and reading comprehension. ${ }^{24}$ The percentage of African-American children under the age of eighteen who live in poverty is almost double that of whites. ${ }^{25}$ The same is true for the number of births to unwed mothers. ${ }^{26}$ Homicide victimization rates for blacks are nearly double the rates for whites. ${ }^{27}$ Incarceration rates for black men are seven times those of white men. ${ }^{28}$ African-American adult men and women have a shorter life expectancy than their white counterparts, ${ }^{29}$ with black infant mortality rates approximately double those for whites. ${ }^{30}$

Each of us is perhaps familiar with one or two of these points of comparison, and it is easy to remain relatively unfazed by evidence of disparity in an isolated aspect of social life. Yet it is more difficult to remain unmoved when confronted by the totality of racial disparity presented here. The collected data create a mosaic image of a racial caste, and as such demand our full attention. It immediately calls into question banalities such as "the civil rights era ended racial discrimination" or "we live in a colorblind society." More importantly, it gives force to the claim advanced by Loury and others that nearly every aspect of our lives is mediated by race. ${ }^{31}$

21 Id. at 175 .

${ }^{22} \mathrm{Id}$. at 176 .

${ }^{23} \mathrm{Id}$. at 184 .

${ }^{24}$ Id. at $180-81$.

${ }^{25} I d$. at 190 .

${ }^{26} I d$. at 196.

27 Id. at 200.

${ }^{28} I d$. at 201 .

29 Id. at 182

30 Id. at 204.

31 See Ian Haney López, The Social Construction of Race: Some Observations on Illusion, Fabrication, and Choice, 29 HARV. C.R.-C.L. L. REV. 1, 3 (1994). López observes:

Human fate still rides upon ancestry and appearance. . . . Race determines our economic prospects. The race-conscious market screens and selects us for manual jobs and professional careers, red-lines financing for real estate, green-lines our access to insurance, and even raises the price of that car we need to buy. Race permeates our politics. It alters electoral boundaries, shapes the disbursement of local, state, and federal funds, fuels the creation and collapse of political alliances, and twists the conduct of law enforcement. In short, race mediates every aspect of our lives. Id.

Lopez and Loury are not alone on this point. Scholars across generations and the color line share in this belief in the salience of race in American culture. See W.E.B. DuBoIs, DuSK OF DAwn 139 (1940) ("[I]n my life, the chief fact has been race - not so much scientific race, as that deep conviction of myriad men that congenital differences among the main masses of human beings absolutely condition the individual destiny of every member of that group."); Alex Aleinikoff, A Case for Race Consciousness, 91 Colum. L. REV. 1060, 1067 (1991) ("While not every decision we make necessarily has a racial 
This is a point that deserves greater prominence than it receives, especially in light of recent efforts underway in California to eliminate racial data collection. Ward Connerly, a member of the University of California Board of Regents and chief proponent of California's Proposition 209, ${ }^{32}$ is currently pushing a "Racial Privacy Initiative" for the March 2004 California ballot that would essentially ban the state from requiring people to check off their race when they apply for a job, register for school, or otherwise engage in state-regulated activities. ${ }^{33}$ If this becomes a national movement, it would be virtually impossible to gauge whether people of color were making progress since public institutions would be banned from asking students and potential hires about their racial and ethnic background. Although proponents of this initiative claim to want to create a "colorblind" society, some argue that the initiative turns a proverbial blind eye to discrimination. ${ }^{34}$ Regardless of where Loury stands on this single issue, however, the collection and presentation of evidence of racial disparity is crucial to his task of identifying and explaining the root causes of racial inequality. While it is true that Loury is principally concerned with providing a theoretical explanation of why racial disparity exists, his failure to discuss in

component, when race is present it almost invariably influences our judgments. We are intensely - even if subconsciously-race-conscious."); Charles Lawrence, The Id, Ego, and Equal Protection: Reckoning with Unconscious Racism, 39 STAN. L. REV. 317, 322 (1987) (“Americans share a common historical and cultural heritage in which racism has played and still plays a dominant role. . . To the extent that this cultural belief system has influenced all of us, we are all racists.”).

32 CAL. CONST. art. I, § 31.

33 See Miguel Bustillo, Ban on Gathering Racial Data on 2004 Ballot, L.A. TIMES, July 16, 2000, at B7. The Racial Privacy Initiative is proposed by the American Civil Rights Coalition, an arm of Ward Connerly's American Civil Rights Institute. Kevin T. Nguyen is the Executive Director of the American Civil Rights Coalition and the official proponent of the Racial Privacy Initiative. According to the organization's website, the Initiative is designed to prevent California's public agencies from classifying "any individual by race, ethnicity, color or national origin in the operation of public education, public contracting or public employment." RACIAL PRIVACY INITIATIVE § 32(a), available at http://www.racialprivacy. org/language.htm (last visited Jan. 22, 2003). Classification is defined as any "act of separating, sorting or organizing by race, ethnicity, color or national origin including, but not limited to, inquiring, profiling, or collecting such data on government forms." Id.

${ }^{34}$ Patricia J. Williams, Racial Privacy, NATION, June 17, 2002, at 9 (arguing that "the Racial Privacy Initiative is not about protecting data from being misused; instead it effectively eliminates data collection at all [and] continues a trend begun by Ronald Reagan and pursued by every Republican administration since limiting the accountability of public institutions by making vital public information unavailable"). Moreover, as Alex Aleinikoff has argued, the choice between colorblindness and color consciousness is, in all likelihood, a false one:

It is apparently important . . . for whites to assert that they are strongly colorblind, in the sense that they do not notice or act on the basis of race. Once can see this at work in such statements as: "I judge each person as an individual." Of course, it cannot be that whites do not notice the race of others. Perhaps what is being said is that the speaker does not begin her evaluation with any preconceived notions. But this is too difficult to believe, given the deep and implicit ways in which our minds are color-coded. To be truly colorblind in this way . . requires color consciousness: one must notice race in order to tell oneself not to trigger the usual mental processes that take race into account.

Aleinikoff, supra note 31, at 1079. 
more detail the nature and extent of actual racial disparity is an omission that may have the effect of leaving some otherwise convincible readers unpersuaded by his argument.

\section{B. The Logic of the Self-Confirming Stereotype}

Loury's argument in earnest begins with an analysis of the role of racial stereotypes in generating and sustaining racial inequality. For Loury, the persistence of racial inequality is intimately linked to our collective reliance upon racial stereotypes. Human beings, according to Loury, are naturally hungry for information that will serve as guideposts when making "choices on matters of consequence." ${ }^{35}$ We classify this information in a variety of ways for our own purposes, and employ what we learn as needed. In addition to classifying features of our environment, we are constantly engaged in the process of classifying human subjects as well. "Race," according to Loury, is simply one of many modes "of perceptual categorization that people use to navigate their way through a murky, uncertain social world." ${ }^{36}$ Under this view, racial classifications are neither necessarily good nor necessarily bad, but happen, because classifying human subjects is a "universal practice, one that lies at the heart of all social cognitive behavior," and visible, physical markers such as color are available criteria that can be used to classify human subjects. ${ }^{37}$

Racial classification, in and of itself, does not cause racial inequality. Problems arise, however, when racial classification takes the form of racial stereotyping - that is, when we take some generalization about a group of people and use it as the basis for interaction with a specific member of that group. As Loury correctly notes, however, not all stereotypes are the same. Some stereotypes are premised upon myth, speculation, or sheer imagination-"blacks are lazy," "Jews are cunning"-while other racial generalizations seem "reasonable" because they are supported by some experience or evidence. $^{38}$

35 LOURY, supra note 11 , at 17.

36 Id. at 16.

37 Id. at $18-19$.

38 Loury's distinction between irrational and rational discrimination is firmly rooted in the economic literature on discrimination. Loury's account of racial discrimination as the product of imperfect information reflects Gary Becker's basic economic theory of race discrimination. According to Becker, racial discrimination is an irrational, "taste-based" discrimination that occurs because the discriminating actor experiences some disutility from associating with the group he dislikes. GARY S. BECKER, THE ECONOMICS OF DisCRIMINATION 16-17 (2d ed. 1971). Applied in the employment context, Becker argued that racial discrimination is inherently inefficient - that it wastes and underutilizes human resources of African Americans by irrationally reducing their employment opportunities, and that it imposes substantial opportunity costs on employers, whose discriminatory practices cause them to pass over, to their own competitive disadvantage, valuable chances to hire African Americans whose services are, comparatively speaking, underpriced. See generally BECKER, supra. Becker's associational preference model of discrimination is considered by some to be "the prevailing economic theory of race discrimination." Richard H. McAdams, Cooperation and Conflict: The Economics of Group Status 
Loury is principally concerned with the latter set of "reasonable" stereotypes because these sorts of generalizations appear correct insofar as they are corroborated by "proof." Loury's claim, however, is that even when there is a reason to believe that members of a group are a certain way based upon prior social interaction, that reason may not only be incorrect, but a product of the social interaction itself. That is, a stereotype may be self-confirming. Loury offers a few examples of how this might occur. Suppose (1) that an employer has a practice of closely observing all new hires during a probationary training period, (2) the employer can observe the mistakes made by new hires, but not the effort exerted during the training period, and (3) the employer will have greater difficulty in dismissing an employee once the training period has been completed. In addition, suppose that an employer generally believes that black hires tend to exert less effort than white hires, and as a result, allows for fewer mistakes to be committed by blacks than by other employees before seeking dismissal of that employee during the training period. ${ }^{39}$ How will the new black hires respond to the employer's behavior?

Loury tells us that if the black hires perceive that the standard to which they are being held is considerably more stringent than the standard imposed upon non-black hires, they will likely reduce the amount of effort expended during the training period because the expected benefit (avoiding dismissal) does not exceed the costs (effort expended to avoid mistakes). The reduction in effort may lead black hires to make a greater number of mistakes, which the observant employer will interpret as confirmation of his initial suspicions regarding the lack of effort by black hires. More importantly, the employer will likely feel justified in imposing the more stringent standard in light of "proof" of racial difference in the effort expended by new hires.

In another example, Loury asks us to suppose that (1) most taxi drivers refuse to stop for young black men after a certain hour for fear of being robbed, (2) that there are some taxi drivers who will stop for anyone, and (3) that there are two types of young black men out there - the law-abiding black man who is simply trying to get home and the black man intent on

Production and Race Discrimination, 108 HARv. L. Rev. 1003, 1033 (1995). For a discussion of the competing view that race-based employment discrimination may be rational and efficient, see RICHARD A. Epstein, Forbidden Grounds: The Case Against Employment Discrimination LaWs 59-78 (1992) (arguing that race-based employment discrimination is often entirely rational and an efficient means of holding down internal frictions that arise from long-term employment contracts, and, where it is rational, it should not be forbidden); Richard A. Epstein, Standing Firm, On Forbidden Grounds, 31 SAN DiEGo L. REV. 1, 54-56 (1994) (arguing that Title VII is inefficient because it fails to allow any room for rational race-based employment discrimination).

Loury's distinction between Becker's form of racial discrimination and racial discrimination that appears rational insofar as the discriminating actor uses distinguishing racial markings as an indicia of some unfavorable trait based upon past experience is also consistent with the economics literature. See Edmund S. Phelps, The Statistical Theory of Racism and Sexism, 62 AM. ECON. ReV. 659 (1973).

39 LOURY, supra note 11, at 29. 
robbery. How might the stereotype of the dangerous young black male be confirmed in this scenario?

Loury reasons that, for the law-abiding men, the long wait for a potential taxi ride will discourage dependence on taxis as a source of transportation. These individuals will find some other means of late-night transportation. However, a person's intent upon robbery will not be similarly discouraged. As Loury explains, "[e]ven though he knows most cabs are unlikely to stop, [the would-be robber] only needs one to do so to get in [a] night's work." ${ }^{40}$ Because taxi drivers' reluctance to stop discourages more law-abiding men than robbers from seeking late-night taxi service, "the set of young black men actually seen to be hailing taxis after dark may come to contain a larger than average fraction of robbers, precisely the circumstance presumed by the drivers in the first place." 41

Both the employer and the taxi drivers' behavior create facts that "proved" the validity of the stereotypes they held. Loury's point, of course, is that there is no intrinsic connection between race and lack of effort or race and criminality. Beliefs and behaviors informed by stereotypes can generate outcomes that appear to justify racially disparate treatment and, as a consequence, generate and reinforce concrete indicia of racial disparity in social and economic life. ${ }^{42}$

Loury's account of the logic of the self-confirming stereotype is similar to research by Stanford psychologist Claude Steele in the phenomenon called "stereotype threat," in which the deployment of negative stereotypes have been shown to affect standardized test performance by students to whom they might apply. ${ }^{43}$ In one experiment, white and black students at

\footnotetext{
${ }^{40}$ Id. at 30 .

${ }^{41} I d$. at 31 .

42 The phenomenon Loury describes is a classic instance of adverse selection, where the process selects against quality in the market. Adverse selection is typically illustrated using an insurance-related hypothetical. Suppose that an auto insurer must predict the probability of a claim in order to set the price of the insurance premium. Further suppose that drivers know more about the probability of a claim than insurers know. Under this set of conditions, drivers with a high probability of a claim will seek insurance, which causes premiums to rise. Some drivers with a low probability of a claim respond to the rise in premiums by dropping their insurance, which causes another rise in premiums, and so forth. This process selects against quality in the market, as more bad drivers seek insurance and more good drivers drop their policies.

Here, the taxi driver's behavior screens out law abiding black patrons, leaving a disproportionate number of non-law abiding blacks in the market for taxi services. For a discussion of the general phenomenon of adverse selection, see George A. Akerlof, The Market for 'Lemons': Quality, Uncertainty and the Market Mechanism, 84 Q.J. ECON. 488 (1970). For a discussion of the general effects of adverse selection on risk pooling, see Mark Pauly \& Sean Nicholson, Adverse Consequences of Adverse Selection, 24 J. Health POL. POL'Y \& L. 921 (1999) (describing the costs of adverse selection); George. L. Priest, The Current Insurance Crisis and Modern Tort Law, 96 YALE L.J. 1521 (1987) (arguing that the crisis in product liability insurance in the United States in the 1980s stemmed mainly from low risk firms dropping out of the insurance market).

43 See Claude M. Steele \& Joshua Aronson, Stereotype Threat and the Test Performance of Academically Successful African Americans, in THE BLACK-WHITE TeST SCORE GAP 401 (Christopher
} 
Stanford University were given twenty-seven difficult questions from the verbal sections of past Graduate Record Exams. ${ }^{44}$ The diagnostic group of students was told that their abilities were being measured; the control group was told that the purpose of the experiment was "to examine the psychology of problem solving." 45 As Steele and Aronson report, black students in the diagnostic group performed far worse than black students in the control group, while white students performed at the same level in both groups. ${ }^{46}$ Steele offered the following explanation for diminished performance on exams that could not be attributed to bias on the part of the test designer nor to inferior skills of the test taker:

African American students know that any faltering could cause them to be seen through the lens of a negative racial stereotype. Those whose self-regard is predicated on high achievement - usually the stronger, more confident students - may feel this pressure so greatly that it disrupts and undermines their test performance. ${ }^{47}$

Steele's analysis, much like Loury's use of the self-confirming stereotype, highlights how stereotypes can be deployed in social interaction to influence and shape outcomes consistent with the stereotype.

Loury's discussion of self-confirming stereotypes, though enlightening, gives me pause for at least three reasons. First, let us assume, as most economists do, that people act in ways that are perfectly rational. Can we confidently say that man as "homo economicus" would respond in such singular fashion? Take Loury's employment example. Loury argues that under such circumstances, the rational response by the African-American hire would be to reduce his effort and, in all likelihood, induce an early dismissal. Yet it would seem equally rational for that same AfricanAmerican hire to continue to put forth the same degree of effort-despite being held to a higher standard - if for no other reason than to remain gainfully employed and to retain the opportunity to earn a living. In other words, it is not entirely clear that this scenario yields only one "rational" outcome.

Second, does it make sense to conclude that every member of a racial group will respond in such a rational and conveniently predictable fashion? Again, consider the employment hypothetical-when faced with an unusually stringent review standard by the employer, would not some blacks

Jencks \& Meredith Phillips eds., 1998); Claude Steel, A Threat in the Air: How Stereotypes Shape Intellectual Identity and Performance, 52 AM. Psychologist 613, (1997); see also Claude M. Steele, Thin Ice: Stereotype Threat and Black College Students, Atlantic Monthly, Aug. 1999, at 44.

${ }^{44}$ See Claude M. Steele \& Joshua Aronson, Stereotype Vulnerability and African-American Intellectual Performance, in Readings About the Social Animal 409, 411 (Elliot Aronson ed., 7th ed. 1995).

${ }^{45} \mathrm{Id}$.

46 Id. at 414.

47 See Steele \& Aronson, supra note 43, at 402. 
choose to "rise to the occasion," so to speak, overperform, and thereby exceed expectations? If so, would the number of would-be superacheivers vary depending upon the employment context - that is, might we expect more superacheivers among the ranks of entry level professionals as compared to unskilled laborers? Similarly, in the taxi hypothetical, might we not expect to find a critical mass of would-be taxi passengers that either call a taxi service directly to reserve a taxi when needed, or who are willing to wait for some taxi to stop rather than arrange for some alternative? In short, why does Loury presuppose that considerations other than efficiency or rationality - such as workers' pride or preferences for taxis over other forms of public transportation - that appear less "rational" at first blush and more difficult to capture and quantify will have little if any impact upon an individual's responsive behavior?

The answer, I suspect, is that Loury, as a trained economist, is doing what he does best-economic modeling of extremely complex behavior. Loury's modeling seems consistent with the classic economics model, which places a premium on rational choice and efficiency insofar as it assumes that people think and act in a perfectly rational manner. ${ }^{48}$ The problem, of course, is that people are not so easy modeled. Recently, behavioral economists have criticized this classic economic model and its reliance upon this assumption of perfect rationality as an inaccurate description of human reality. The basic theme advanced in this burgeoning area of thought is that people are not perfectly rational, and that a host of nonrational factors and biases often inform human decisionmaking. ${ }^{49}$ In light of credible evidence to suggest that individuals frequently act in ways that are incompatible with the assumptions of rational choice theory, ${ }^{50}$ it is likely that Loury's classic economic modeling presupposes a level of simplicity, rationality and predictability in behavioral responses that does not square with the human experience. ${ }^{51}$

\footnotetext{
48 See, e.g., Richard A. Posner, ECONOMiC ANALYSis OF LAW 3 (5th ed. 1998) ("The task of economics ... is to explore the implications of assuming that man is a rational maximizer of his ends in life...."). For a review of rational choice principles in economics and their extension in political science, see Donald P. Green \& Ian Shapiro, Pathologies of Rational Choice Theory 1-12 (1994). For a general defense of rational choice theory, see Dennis Chong, Rational Choice Theory's Mysterious Rivals, 9 CRITICAL REV. 37 (1995).

49 Behavioral economic research typically focuses on decision-making heuristics and biases that are inconsistent with rational choice economics. See, e.g., Amos Tversky \& Daniel Kahneman, Judgment Under Uncertainty: Heuristics and Biases, 185 SCI. 1124, 1130 (1974). Scholars have begun to incorporate the behavioral economics viewpoint into legal analysis as well. See, e.g., Russell Korobkin \& Chris Guthrie, Psychological Barriers to Litigation Settlement: An Experimental Approach, $93 \mathrm{MicH}$. L. REV. 107 (1994) (reviewing history of behavioral economics as applied to the law).

${ }^{50}$ See, e.g., Russell B. Korobkin \& Thomas S. Ulen, Law and Behavioral Science: Removing the Rationality Assumption from Law and Economics, 88 CAL. L. REV. 1051, 1102-26 (2000) (discussing evidence that people frequently act in ways that are incompatible with the assumptions of rational choice theory).

${ }^{51}$ Whether personal pride, emotions, concepts of justice, or "other regarding behaviors" can be ef-
} 
Finally, how much of current racially disparate treatment and ensuing disparity is premised upon these self-confirming stereotypes? While it is possible that a great deal does take this form, it seems at least as likely that the same amount if not more is premised upon "unreasonable" stereotypes or brute racism. The revelation of fairly recent episodes of vulgar discrimination in the assessment of life insurance premiums, ${ }^{52}$ the sale of automobiles,${ }^{53}$ employment decisionmaking, ${ }^{54}$ and criminal victimization ${ }^{55}$ reminds us that brute racism is alive and well. To his credit, Loury tells us that selfconfirming stereotype-induced behavior is not "the be-all and end-all of racebased behavior in society." 56 But it must account for a great deal of it —or at least the most meaningful form of racialized behavior that leads to racial inequality - as much of Loury's argument seems to hinge upon this point.

\section{Racial Stigma and the Seductiveness of Race-Thinking}

At the heart of Loury's analysis is his account of the role of racial stigma in perpetuating racial inequality. After all, stereotypes perpetuate racial inequality only to the extent that we feel comfortable and confident relying upon them as credible guideposts in social interaction. ${ }^{57}$ If there was some reason to think that the connection between race and a host of other beliefs was wholly artificial, then it would stand to reason that the natural inclination toward better informed social decisionmaking would

fectively modeled using rational choice theory alone remains a source of continued debate. Compare Christine Jolls et al., A Behavioral Approach to Law and Economics, 50 Stan. L. Rev. 1471 (1998) (noting that empirical research by behavioral economists indicates that economic subjects often act in ways that do not fall within the neoclassical definition of "rationality"), with Richard A. Posner, $R a$ tional Choice, Behavioral Economics, and the Law, 50 STAN. L. REV. 1551, 1552, 1559 (1998) (arguing that many of the insights of behavior economics are "already a part of economic analysis of law, which long ago abandoned the model of hyperrational, emotionless, unsocial, supremely egoistic, nonstrategic man" and that the behavioralists' fixation upon other nonrational behaviors robs behavioral economics of its predictive power as a theory). For an overview of the debate and a discussion of the concept of "rationality" in neoclassical economics and the law and economics movement, see Jeanne L. Schroeder, Rationality in law and Economics Literature, 79 OR. L. REV. 147 (2000).

${ }^{52}$ See Ellen Kelleher, MetLife Settles Class-Action Suit, Fin. Times, Aug. 30, 2002, at 2 (reporting that MetLife had settled a massive class-action lawsuit in which the plaintiffs alleged the New York insurer charged black clients more money for certain life insurance policies from 1901 until 1972).

${ }^{53}$ See supra note 5.

${ }^{54}$ See Henry Unger, Coke To Settle Racial Suit with \$192.5 Million Deal, AtLAnTA J.-Const., Nov. 17, 2000, at Al (announcing settlement of lawsuit in which plaintiffs claimed that the Coca-Cola Company had discriminated against black salaried employees in pay, promotions and performance evaluations).

55 See Joyce King, Hate Crime: The Story of a Dragging in Jasper, TeXas (2002) (describing the racially motivated 1998 mutilation and murder of James Byrd, Jr. by three white men).

${ }^{56}$ LOURY, supra note 11, at 34.

${ }^{57}$ Moreover, that fact that one has come to learn stereotypes does not necessarily mean that one must act upon them. See Jody Armour, Stereotypes and Prejudice: Helping Legal Decisionmakers Break the Prejudice Habit, 83 CAL. L. REV. 733, 749 (1995) (observing that although ethnic attitudes and stereotypes are part of a society's social heritage, "people do not always endorse the knowledge structures that socialization has established in their memories"). 
cause some of us to abandon stereotype-informed thinking. Why, in a realm of uncertainty, might a person cling to stereotypes nonetheless? Why not experiment in social interaction?

The answer, according to Loury, is that one may be willing to revise one's beliefs, but only when observed conditions and behaviors would seem to defy rather than affirm the beliefs. Thus, as Loury points out:

[I]f a racial disparity does not strike a powerful observer as being disturbing, anomalous, contrary to his unexamined and perhaps not even consciously espoused presumptions about the nature of the social world, then he may make no special effort to uncover a deeper (than race) cause of the disparity. ${ }^{58}$

This, of course, raises a deeper question - namely, why would it not occur to the discriminator that the disparity is a result of his own action? The reason, according to Loury, is that at bottom, there is a profound awareness of the racial "otherness" of blacks that is deeply ingrained in the American cultural consciousness - an "otherness" that brings to mind a host of negative presumptions, taboos, and suspicions. This, he explains, is the territory "of racial stigma, of dishonorable meanings socially inscribed on arbitrary body marks, of "spoiled collective identities." 59 When the subjects are racially stigmatized, the prospects of undoing racial beliefs that generate racial disparity are sharply diminished. A discriminator refuses to learn differently because he does not think learning will pay. Challenging stereotypes will be perceived to be a waste of time. And "[u]nless he is willing to experiment, to test the limits of his prior generalization as a matter of principle, he will retain his false belief." 60 When a group is stigmatized in this manner, to the point where social identity ascribed to group members by external observers essentially devalues their humanity, the group suffers from what Loury calls a "spoiled collective identity."

Loury's invocation of racial stigma and spoiled identity is consistent with the theory of racism advanced by George Fredrickson. For over three decades, Frederickson has advanced the theory that racism originates from a mindset fixated upon stigmatized racial difference that is "permanent and unbridgeable." ${ }^{61}$ As Frederickson observes:

This sense of difference provides a motive or rationale for using our power advantage to treat the ethnoracial Other in ways that we regard as cruel or unjust if applied to members of our own group. The possible consequences of this nexus of attitude and action range from the unofficial but pervasive social dis-

\footnotetext{
${ }^{58}$ LOURY, supra note 11, at 42.

59 Id. at 59 .

${ }^{60} \mathrm{Id}$. at 64 (emphasis removed). This explanation echoes the sentiment expressed by Alex Aleinikoff in his own meditation on the durability of racial stereotypes in American thinking: "It is often more likely that our mental schema will influence how we understand new information than it is that the new information will alter our mental schema." Aleinikoff, supra note 31, at 1067.

${ }^{61}$ Frederickson, supra note 2, at 9 (2002); see also GEORge Frederickson, The ArRogance of Race (1988); George Frederickson, The Black Image In the White Mind (1971).
} 
crimination at one end of the spectrum to genocide at the other .... In all manifestations of racism from the mildest to the most severe, what is being denied is the possibility that the racializers and the racialized can coexist in the same society, except perhaps on the basis of domination and subordination. ${ }^{62}$

Importantly, this concept of racism is contingent upon the rejection of any notion that an individual member of a racially stigmatized group can remove racial stigma through alternation or reformation of one's racial identity. ${ }^{63}$ Loury maintains that racial stigma of African Americans - this "spoiled collective identity"-is rooted in the institution of slavery. Here, Loury relies heavily upon the insights of Orlando Patterson. In Slavery and Social Death, ${ }^{64}$ Patterson argues that in addition to providing for property in man, slavery allowed for "the permanent, violent domination of natally alienated and generally dishonored persons." ${ }^{\prime 65}$ Loury, summarizing Patterson's work, observes that "[m]asters derive honor from their virtually unlimited power over slaves, who are radically marginalized because their very social existence is wholly dependent on relations with their masters." 66

Both Loury and Patterson are correct to point to racial dishonor as crucial to the perpetuation of slavery and the racial pigmentocracy that followed in the form of segregation. Indeed, this was one of the principle insights offered by Alexis de Tocqueville in his meditation on "The Three Races in the United States." ${ }^{7}$ Writing in 1832, Tocqueville observed:

The greatest difficulty in antiquity was that of altering the law; among the moderns it is of altering the customs .... The tradition of slavery dishonors the race, and the peculiarity of the race perpetuates the tradition of slavery.... Thus, the Negro transmits the eternal mark of his ignominy to all his descendents; and although the law may abolish slavery, God alone can obliterate the traces of its existence .... You may set the Negro free, but you cannot make him otherwise than an alien to the European. ${ }^{68}$

For Tocqueville, the omnipresence of slavery and its concomitant rhetoric of Negro inferiority were the most powerful obstacles to the achievement of racial equality. As Tocqueville observed:

There is a natural prejudice that prompts men to despise whoever has been their inferior long after he has become their equal; and the real inequality that is produced by fortune or by law is always succeeded by an imaginary inequality that is implanted in the manners of people. ${ }^{69}$

\footnotetext{
62 GEORGE M. FrederickSON, RACISM: A SHORT History 4 (2002).

${ }^{63} \mathrm{Id}$.

${ }^{64}$ PATtERSON, supra note 4.

${ }^{65} \mathrm{Id}$. at 13

${ }^{66}$ LOURY, supra note 11, at 68.

${ }^{67}$ DE TOCQUEVILLE, supra note 1, at 331-434.

${ }^{68} I d$. at 358 .

${ }^{69} I d$. at 357.
} 
But it bears emphasis that the concept of racial dishonor serves not only to denigrate the racial identity of blacks as a social group, but might also be understood as possessing a reflexive quality that has the opposite affect on the racial identity of whites as a group. Where slavery dishonors blacks, it also plays a crucial role in shaping and maintaining white identity. As Edgar Gardner Murphy wrote in Problems of the Present South, ${ }^{70}$ "it is certainly no tribute to the Caucasian to assume that his own proud and historic race, with its centuries of start and the funded culture of all civilization at its command, cannot keep ahead of the $[\mathrm{N}]$ egro, no matter what the $[\mathrm{N}]$ egro can know or do."71 The role of racial stigma in shaping presumptions of white capacity — of racial superiority and cultural distinctiveness - is an important corollary to Loury's main point on racial stigma. To hold fast to notions of black American racial inferiority is, to a certain extent, to affirm what it means to be white in America.

To question the legitimacy of black American racial stigma, then, is to cast doubt upon a fundamental component of white identity. Loury points out that to properly confront racial stigma, whites first must give "the presumption of equal humanity" to black Americans. Yet he quickly concedes that this presumption is not freely given in American culture. ${ }^{72}$ He fails to elaborate on why this is so, but the answer may lie in this corollary point: to extend a presumption of equal humanity to African Americans requires white Americans to give up something of immense value, some constituent element of the constructed white American identity. ${ }^{73}$

Loury's emphasis on racial stigma, while answering some questions, raises many others. For instance, is there a reason to think that racial stigma is insurmountable in the case of African Americans? Certainly, other groups - Asian immigrants and Jews, for example - were historically stigmatized, but have largely overcome these social impediments. Why does similar success for African Americans remain so elusive?

Moreover, does racial stigma maintain the same form over time? Loury's analysis presupposes that racial dishonor from slavery-what Loury describes as "an entrenched if inchoate presumption of inferiority, of

\footnotetext{
70 Edgar Gardner Murphy, Problems of the Present South (Negro Univ. Press 1969) (1904).

71 Id. at 81 .

72 LOURY, supra note 11 , at 87.

73 See Crenshaw, supra note 10, at 1373 (observing the ways in which white identity is constructed in opposition to black identity); see also Cheryl I. Harris, Whiteness as Property, 106 HARV. L. REV. 1707, 1720-21 (1993) ("Because whites could not be enslaved or held as slaves, the racial line between white and Black was extremely critical .... White identity and whiteness were sources of privilege and protection; their absence meant being the object of property."). For an interesting discussion of how the construction of white identity plays out in the immigrant context, see BRUCE NELSON, DIVIDED WE STAND: AMERICAN WORKERS AND THE STRUGGLE FOR BLACK EQUALITY 200 (2001) (observing how Irish immigrants would seek to establish their white identity by "creating social and psychological distance between themselves and African Americans and, as a first priority, severing the occupational and residential ties that linked the two groups in the popular imagination").
} 
moral inadequacy, of unfitness for intimacy, of intellectual incapacity"74 has carried forward to the present largely unchanged. While this may be true to some extent, it seems the case that racial stigma might be more powerfully understood as possessing a dynamic character. The content of racial stigma must be filtered through human experience. For stigma to have any longevity, then, each successive generation must find its own reasons to hate.

Nothing has proven more corrosive of modern American race relations than the perceived link between blackness and rampant criminality. As Katheryn Russell writes, "[a] person would have to live as a hermit to avoid seeing crime portrayed in shades of Black." "75 The connection is more than one of media imagery - we also have racial language, such as "black-onblack crime" and "black criminality." 76 This link between blackness and criminality also manifests itself in racially disparate law enforcement policy. Such policy, according to Randall Kennedy, creates cycles of resentment:

Many law-abiding blacks resent the racial discrimination to which they are subjected [because they are treated like] criminals with whom they are lumped by dint of color. Many of them voice their resentment by attacking as "racist" those who view blackness as a proxy for enhanced criminality [which,] in turn, deepens the anger of those who view [such charges] as yet another way of denying that blacks, too, bear some responsibility for the sorry state of American race relations. ${ }^{77}$

Second, and related, is the perceived link between blackness and moral or cultural depravity. The connection is most pronounced in discussions regarding the propriety of assisting the "black underclass." As Dorothy Roberts observed,

black responsibility for the effects of racism borrows from the long-standing ideology that blames the poor, because of their dependence mentality, deviant family structure, and other cultural depravities, for their poverty. The rhetoric describing the undeserving poor, although encoded in race-neutral language, is increasingly racialized. Americans conjure up the image of Willie Horton and black "welfare queens" when they discuss the "underclass," whose intractable poverty stems from their own deplorable behavior rather than societal conditions. $^{78}$

Perceptions of modern day criminality and cultural depravity would thus seem to provide sufficient grist to sustain the racial stigma mill, independ-

\footnotetext{
74 Id. at 70.

75 KATHERYN Russell, THE COLOR OF CRIME 110 (1998).

${ }^{76} \mathrm{Id}$.

77 Randall Kennedy, Race, Crime and Law, at x-xi (1997).

78 Dorothy Roberts, The Priority Paradigm: Private Choices and the Limits of Equality, 57 U. PITT. L. ReV. 363, 386 (1996) (footnotes omitted).
} 
ent of attitudes or beliefs that harken back to slavery days.

Loury acknowledges as much when he writes "[o]bviously, slavery has not been the only historical event relevant to the making of racial stigma .... Social perceptions of racial worth have also been shaped by more recent events." 79 But how much is attributable to slavery, and how much is attributable to "so-called pathological behaviors often associated with the so-called black underclass?" 80 I suspect that there is not only a fundamental lack of consensus as to the root cause or causes of modern forms of racial stigma, but that approaches to the elimination of racial stigma will vary depending upon its perceived origin. ${ }^{81}$

\section{Critique of Liberal Individualism}

In the final stage of his argument, Loury argues that public policy efforts ought to be aimed at eliminating the lingering effects of racial stigma (we might call this substantive racial justice) rather than focus on procedural mechanisms that attempt to remedy racial transgressions (this might be called procedural racial justice). Loury argues that we should focus on the problem of racial stigma rather than prototypical racial discrimination because the concept of racial discrimination "cannot reach the problem of 'development bias,' a term Loury employs to describe "the systematic denial of opportunity to acquire productivity." 82 Process-based solutions to proscribe discrimination "in contract"- that is, discrimination in formal

\footnotetext{
${ }^{79}$ LOURY, supra note 11, at 73.

80 Id. at 73

${ }^{81}$ Scholarly exploration of the ways in which identified pathological customs and habits of blacks
} have served to destabilize and undermine black communities has added an interestingly layer of complexity to our appreciation of the persistence of racial disparities in social and economic life. For instance, some have argued that exogenous forces, such as racism and economic discrimination, are no longer serious obstacles to African American advancement. See, e.g., JoHN H. MCWHORTER, Losing the Race: Self-Sabotage IN Black America (2000) (arguing that African Americans are not achieving as much as they could because of a pervasive cult of "victimology" and "separatism" and a pervasive ethic of anti-intellectualism). Others, however, persuasively assert that the persistence of pathological behaviors by members of the so-called black underclass have deep, structural causes that make elimination of such behaviors exceedingly complex. See Douglas S. MASSEY \& NANCY A. Denton, American Apartheid: Segregation AND the Making of AN Underclass (1993) (examining how racial and residential segregation aid in the perpetuation of black poverty, crime, and social disorder); William J. Wilson, The Truly Disadvantaged: The InNer City, the Underclass, AND PUBLIC POLICY 121 (1987).

$[\mathrm{T}]$ hose who argue that the deteriorating economic plight of the truly disadvantaged minorities can be satisfactorily addressed simply by confronting the problems of current racial bias fail to recognize how the fate of these minorities is inextricably connected with the structure and function of the modern American economy. ... . [P]olicies that do not take into account the changing nature of the national economy-including its rate of growth and the nature of its variable demand for labor; the factors that affect industrial employment, such as profit rates, technology, and unionization; and patterns of institutional and individual migration that result from industrial transformation and shifts - will not effectively handle the economic dislocation of low-income minorities.

Id.

${ }^{82}$ LOURY, supra note 11 , at 93. 
transactions - does not reach discrimination "in contact"- that is discrimination in the informal, private spheres of life.

For Loury, human social and economic development is closely tied to this latter, complex set of private affiliations:

Each individual is socially situated, and one's location within the network of social affiliations substantially affects one's access to various resources. Opportunity travels along the synapses of these social networks .... An individual's inherited social situation plays a major role in determining his or her ultimate economic success. ${ }^{83}$

Because racial stigma infects these informal networks, "[s]ome important part of racial inequality . . . arises from . . . their 'social otherness' [and] inhibits the development of their full potential." ${ }^{4}$ More importantly, "an individual's opportunities to acquire skills depend on present and past skill attainments by others in the same racial group." 85

Loury therefore concludes that present inequality among individuals and between groups must embody the social and economic disparities that have existed in the past to some degree. ${ }^{86}$ But as Loury points out, "[i]f the past disparities are morally illegitimate, the propriety of the contemporary order must also be called into question." 87 For this reason, he calls upon the cultural elite to take the history of racial subjugation seriously - to "take responsibility for such situations as the contemporary plight of the urban black poor, and to understand them in a general way as a consequence of an ethically indefensible past." 88

For Loury, this means that we should reject colorblind approaches in favor of race-sighted policies. Colorblindness, which is rooted in liberal individualism, looks only to procedural fairness in the public sphere and ignores both historical disadvantage and present-day disadvantage engendered through discrimination in the informal private sphere. By contrast, race-sighted policies aim squarely at promoting "racial egalitarianism"-the reduction of inequities of wealth and power between racial groups. ${ }^{89}$ The move to race sightedness should be undertaken selfconsciously, according to Loury. We must overcome indifference to racial inequality and treat it as a national problem for which each of us bears some responsibility. This comprehensive moral vision should prompt us to ask, "What manner of people are WE who accept such degradation in our midst?"90 A meaningful response, says Loury, must entail the embrace of

${ }^{83} \mathrm{Id}$. at 102.
${ }^{84} \mathrm{Id}$.
${ }^{85} \mathrm{Id}$. at 103.
${ }^{86} \mathrm{Id}$.
${ }^{87} \mathrm{Id}$.
${ }^{88} \mathrm{Id}$. at 127.
${ }^{89} \mathrm{Id}$. at 112.
${ }_{90} \mathrm{Id}$. at 159. 
race-sighted policies designed to "eliminate the objective disparity in economic and social capacity that . . . continue[s] to characterize the social structure of American public life [and] constitute[s] the most morally disturbing remnant of this nation's tortured racial past." ${ }^{\prime 1}$

This is arguably new territory for Loury, a trained economist, who spent the last twenty or so years defending majoritarian efforts to curtail liberal racial policy aimed at eliminating both the incidents and the lingering effects of racial discrimination. In his infamous essay Beyond Civil Rights, published the New Republic in 1985, Loury offered the following criticism of prevailing efforts to empower blacks through civil rights legislation:

Many, if not most, people now concede that not all problems of blacks are due to discrimination, and that they cannot be remedied through civil rights strategies or racial politics. I would go even further: using civil rights strategies to address problems to which they are ill-suited thwarts more direct and effective action. Indeed, the broad application of these strategies ... threatens to make it impossible for blacks to achieve full equality in American society. ${ }^{92}$

Early on in his career, Loury espoused the view that the greatest threat to racial equality was no longer "white racism" per se, but problems inherent in black people themselves. Blacks, according to a younger Loury, were their own worst enemy-agents of their own underdevelopment. His writings during this period were deeply critical of affirmative action and government aid strategies. Instead, Loury argued that the solution to racial disparity could be found through strategies of colorblindness, self-help and entrepreneurialism. ${ }^{93}$

The shift in Loury's analysis is intriguing not only because it stands in such strong contradiction to previously held views, but because in making the shift to the left, Loury also replicates the weakness inherent in many structural equality arguments. First, Loury unjustly minimizes the successes achieved through conventional process-based antidiscrimination policy. Although a good deal of discrimination continues to take place in the private spheres of life, a great deal of racial progress has occurred precisely because overt acts of formal racial discrimination in employment, education and politics have been outlawed. ${ }^{94}$ So formal

91 Id. at 169.

92 Glenn C. Loury, Beyond Civil Rights, New RePUBLIC, Oct. 7, 1985, at 22.

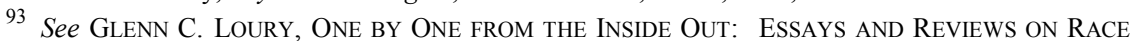
AND RESPONSIBILITY IN AMERICA (1995) (providing examples of Loury's approach to colorblindness and self-help philosophy); see also Glenn C. Loury, Performing Without a Net, in THE AfFIRMATIVE ACTION DEBATE 49, 59 (George E. Curry ed., 1996) ("I am also convinced that racial preferences in hiring, educational opportunities and contracting do not provide a solution for this problem.").

94 See Civil Rights Act of 1964, Pub. L. No. 88-352, tit. VII, 78 Stat. 253 (codified as amended at 42 U.S.C. $\S \S 2000 \mathrm{e}-2000 \mathrm{e}-17$ (1988)) (outlawing discrimination in employment); Civil Rights Act of

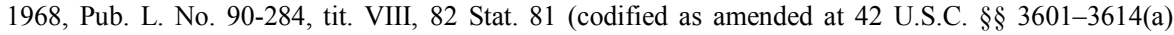
(1988)) (outlawing discrimination in housing); Civil Rights Act of 1964, Pub. L. No. 88-352, tit. II, 78 
civil rights protection not only matters, but would appear to matter a great deal. Indeed, this is precisely the fault line that separates critical race theorists from their theoretical cousins in Critical Legal Studies. After the passage and implementation of the Civil Rights Acts of 1964 and 1965, scholars in the Critical Legal Studies movement argued that it made little sense to rely upon civil rights to achieve racial justice because civil rights are merely an extension of the legal system that legitimates and perpetuates the very racial inequality that it now purports to remedy. ${ }^{95}$ Race theorists, such as Kimberlé Crenshaw, Harlon Dalton, and others, ${ }^{96}$ however, quickly pointed out that African Americans did not possess the luxury of avoidance of legal strategies for racial progress. Indeed, as Crenshaw argued,

the civil rights movement [should be understood] as a radical challenge to the dominant order even though co-optation has been and remains an ever-present

Stat. 243 (codified as amended at 42 U.S.C. $\S \S 2000 a-2000 \mathrm{a}-6$ (1988)); Voting Rights Act of 1965, Pub. L. No. 89-110, 79 Stat. 437 (codified as amended at 42 U.S.C. $\S \S 1973-1973 p$ (1988)) (outlawing discrimination in voting); Brown v. Bd. of Educ., 347 U.S. 483 (1954) (outlawing discrimination in public education); Heart of Atlanta Motel v. United States, 379 U.S. 241 (1964); Katzenbach v. McClung, 379 U.S. 294 (1964) (outlawing discrimination in public accommodations). The literature suggests there may be some connection between economic progress of African Americans and civil rights initiatives. See Francine D. Blau et al., The Economics of Women, Men, And Work 220-21 (3d ed. 1998) (discussing studies examining the effectiveness of antidiscrimination law in reducing gender and racebased pay disparity); Paul Burstein \& Mark Evan Edwards, The Impact of Employment Discrimination Litigation on Racial Disparity in Earnings: Evidence and Unresolved Issues, 28 LAW \& SoC'Y REV. 79 (1994) (arguing that litigation victories are linked to long-term increases in African American earnings); John J. Donohue III \& James Heckman, Continuous Versus Episodic Change: The Impact of Civil Rights Policy on the Economic Status of Black, 29 J. ECON. LiTERATURE 1603, 1603-04 (1991) (noting that African American economic advancement may be due, in part, to advances in civil rights). For a discussion of the importance of civil rights in the pursuit of racial justice more generally for African Americans, see TuSHNET, supra note 7; Crenshaw, supra note 10, at 1366-69, 1384-87. But see William Julius Wilson, The Truly Disadvantaged: The Inner City, the Underclass, and PuBLIC POLICY 55-62, 143-44 (1987) (noting that the success of the civil rights movement further exacerbated the difficulties of the African American poor and contributed to their social isolation because integration allowed many middle-class blacks to move to the suburbs and drain the reservoir of available of role models and resources).

95 See Alan Freeman, Legitimizing Racial Discrimination Through Antidiscrimination Law: A Critical Review of Supreme Court Doctrine, 62 MINN. L. REv. 1049 (1978). For examples of works espousing this view more generally, see MARK KeLman, A Guide to CriticAl Legal StUdies (1987); Roberto Mangabiera Unger, The Critical Legal Studies Movement $36-40$ (1986); The Politics of LaW: A Progressive CritiQue (David Kairys ed., 1982); Symposium, Critical Legal Studies, 36 Stan. L. Rev. 1 (1984); Gerald E. Frug, The Ideology of Bureaucracy in American Law, 97 HaRV. L. Rev. 1276 (1984); Peter Gabel, Reification in Legal Reasoning, 3 ReS. L. \& Soc. 25 (1980); Mark Tushnet, An Essay on Rights, 62 TeX. L. REV. 1363 (1984).

96 See, e.g., Anthony E. Cook, Beyond Critical Legal Studies: The Reconstructive Theology of Dr. Martin Luther King, Jr., 103 HARV. L. REV. 985 (1990); Richard Delgado, The Etheral Scholar: Does Critical Legal Studies Have What Minorities Want?, 22 HARV. C.R.-C.L. L. REV. 300 (1987); Mari J. Matsuda, Looking to the Bottom: Critical Legal Studies and Reparations, 22 HARV. C.R.-C.L. L. REV. 323 (1987); Patricia J. Williams, Alchemical Notes: Reconstructing Ideals from Deconstructed Rights, 22 HARV. C.R.-C.L. L. REV. 401 (1987). 
threat to the movement. [A] realistic examination of the limited alternatives available to Blacks [at that time] makes it clear that legal reform was a viable pragmatic strategy for Blacks confronted with the threat of unbridled racism on one hand and co-optation on the other. ${ }^{97}$

Or, as Dalton put it, "the quite distinct social circumstance of white males has led to a 'rights critique' that is oblivious to, and potentially disruptive of, the interests of people of color."98 Each of these writers understood the limits of liberal individualism to remedy structural racial disparities in wealth and politics, but nevertheless appreciated the role of law in securing meaningful and important advancements, such as the elimination of formal inequality. ${ }^{99}$

Second, although substantive equality is desirable, it is far from clear how this should be attained. Loury points out that his argument for racial egalitarianism should not be construed as an argument in favor of reparations. ${ }^{100}$ Race-sighted policies should be adopted "not so much to "compensate' for an ethically troubled past as to adopt the 'right interpretation' of it."101 But what form should policies based upon the "right interpretation" take? Here, Loury is conspicuously silent. This silence is, in many ways, unsurprising, as silence with respect to program and implementation is a well-known characteristic of leftist structural social criticism. ${ }^{102}$

Finally, if Loury is concerned with the elimination of racial dishonor, it remains somewhat unclear how the bestowal of substantive equality will accomplish this end. As both Tocqueville and Patterson observed, the bestowal of freedom and civil rights do little to restore honor. Bestowals of wealth, education, and political power may make living in a state of dishonor more bearable to say the least, but none of these remedies strike one as honor restorative. If the bestowal of honor is contingent upon extending a presumption of humanity to African Americans, it is unclear how structural equality will engender the shift in the minds and hearts of whites needed to accomplish this deeply personal task.

97 Crenshaw, supra note 10, at 1335.

98 Harlon Dalton, The Clouded Prism, 22 HaRV. C.R.-C.L. L. REV. 435,440 (1987).

99 See Crenshaw, supra note 10, at 1383-84.

${ }^{100}$ LOURY, supra note 11 , at 127.

$101 \mathrm{Id}$.

102 See, e.g., Phillip E. Johnson, Do You Sincerely Want To Be Radical?, 36 StAN. L. ReV. 247, 259-69, 281-89 (1984) (arguing that critical legal studies scholars refuse to address practical issues and have no positive political programs); Louis B. Schwartz, With Gun and Camera Through Darkest CLSLand, 36 STAN. L. REV. 413, 448-52 (1984) (arguing that critical legal studies writings offer grotesque and irresponsible proposals, not viable alternatives). For examples of critical legal studies-inspired positive programs, see Gerald Frug, The City as a Legal Concept, 93 HARV. L. REV. 1057 (1980); Karl Klare, Judicial Deradicalization of the Wagner Act and the Origins of Modern Legal Consciousness, 1937-1941, 62 MinN. L. REV. 265 (1978); William H. Simon, Visions of Practice in Legal Thought, 36 STAN. L. REV. 469 (1984). 


\section{IMPLICATIONS AND CONCLUSIONS}

Professor Loury's Anatomy of Racial Inequality is a powerfully argued meditation on the structure of racial inequality in America. In his concluding chapter, Loury identifies essentially "two big ideas" emerging from the text: (1) that the prevailing, process-based approach to remedying racial inequality that is grounded in liberal individualism is inadequate and (2) that racial stigma - as opposed to racial discrimination - is the problem that must be confronted in order to fully address the crisis of social exclusion and economic disadvantage among African Americans. ${ }^{103}$

There are, however, a number of other critical insights that can be drawn from Loury's work. As an initial matter, Loury's position acknowledges and affirms the prevailing view among the critical left that a great deal of racial interaction that operates to the detriment of blacks is "automatic" - that is, such behaviors are, in many ways, historically conditioned and thus go unquestioned by the actor and by those around him. ${ }^{104} \mathrm{He}$ gives credence to the often-contested proposition that racial stereotypes are deeply rooted in the American cultural consciousness. More importantly, he highlights the seductiveness of racially destructive thinking. It is easy to forget that we are a nation forged in the crucible of racial inequality. Loury reminds us that our unsettling racial past is vitally relevant to shaping our current racial dispositions, and in the process, offers a striking refutation of the conservative view that America's racial history is somehow irrelevant and that "one gets beyond racism by getting beyond it now." 105 To take seriously the problem of racial inequality, we must first confront and come to terms with this ugly feature of our national character and shared racial history.

A second crucial implication of the text is related to the first - that the behaviors that generate and sustain racial inequality, though historically conditioned, are not unconscious or unthinking. To the contrary, such behaviors are very much intentional conduct insofar as they are representative of a wholesale acceptance of stereotypes and of conscious indifference to the structural disparity that ensues. In this sense, Loury does not absolve

\footnotetext{
103 LOURY, supra note 11 , at 167.

104 For a discussion of racism as automatic or unconscious behavior, see Barbara J. Flagg, "Was Blind, But Now I See": White Race Consciousness and the Requirement of Discriminatory Intent, 91 Mich. L. ReV. 953 (1993); Peggy C. Davis, Law as Microaggression, 98 YALE L.J. 1559 (1989); Sheri Lynn Johnson, Unconscious Racism and the Criminal Law, 73 CoRNell L. Rev. 1016 (1988); Charles R. Lawrence III, The Id, the Ego, and Equal Protection: Reckoning with Unconscious Racism, 39 STAN. L. REV. 317 (1987). For a discussion of unconscious racism applied in the environmental law context, see Edward P. Boyle, It's Not Easy Bein' Green: The Psychology of Racism, Environmental Discrimination, and the Argument for Modernizing Equal Protection Analysis, 46 VAND. L. REV. 937 (1993) (arguing that equal protection analysis of environmental racism should not depend on a showing of discriminatory intent because much racism is unconscious and reflexive).

105 William Van Alstyne, Rites of Passage: Race, the Supreme Court, and the Constitution, $46 \mathrm{U}$. CHI. L. REv. 775, 809 (1979).
} 
bad actors of responsibility. This account of racial inequality is not so much about the experiences of blacks who suffer disparity as it is an account of the effect of racist inflection upon whites, and what is required to overcome this effect.

But while Loury's focus is properly positioned upon whites, he makes clear that the problem of racial inequality ought not be born by any single group. Loury, then, reflects the prevailing moralistic view of the civil rights era that racial discrimination and inequality should be viewed as national crisis. In this way, Loury invokes a collective moral aesthetic that has been sorely lacking in recent meditations on the race question. Race has always been a constituent component in the construction of American nationhood and empire. We must ask ourselves, "What manner of people are we TODAY" to allow racial inequality to persist? This proposition makes an important challenge to the historic view that racial equality is a functional impossibility. It was once widely believed that "[n]o two free races, remaining distinctly apart, can advance side by side, without a struggle for supremacy." 106 Consider the 1884 comments of Senator John T. Morgan of Alabama:

The greater their personal successes may be, the more they will feel the pressure of caste, and their advancement in enterprises which may bring them personal honor and wealth will be checked by the jealousy of caste, so that race prejudice will forever remain as an incubus on all their individual or aggregated efforts. ${ }^{107}$

Loury's book offers a crucial counterpoint to this anachronistic view on race and the prospects of eliminating racial prejudice.

At the same time, however, Loury's book proves deeply unsettling from a legal perspective insofar as he seems to expose the limits of what law can do for the cause of racial justice. To paraphrase a point made by Professor Karl Llewellyn during the civil rights era, we cannot expect to legislate a racial "kiss and make up."108 Yet Loury's analysis would seem to require something like this. If the problem is ultimately one of extension of the presumption of humanity and restoration of honor, what more can law do? The history of the civil rights struggle is, in a very real sense, the

106 E.W. Gilliam, The African in the United States, POPULAR SCI. MonTHLY, Feb. 1883, at 440.

107 John T. Morgan, The Future of the Negro, N. AM. REV., July 1884, at 83-84.

108 See Karl Llewellyn, What Law Cannot Do For Inter-Racial Peace, 3 VILL. L. ReV. 30 (1957). Llewellyn used this phrase in responding to anti-civil rights advocates that "you cannot 'legislate' a change of heart or 'legislate' friendship or even tolerance or any other thing of mind or spirit or attitude." Id. at 32. Llewellyn conceded this point:

One can accept the slogan so far as concerns any direct command by way of the law-government of a many-wayed, many-grouped, society in rapid movement. "Kiss and make-up," even inside the family, is a command which presupposes a pre-existing, a going, a lasting regime that offers a basis for resumed relations, for revived and remembered affections and patterns of team-work.

Id. However, Llewellyn was quick to point out that law can do "queer, slow things" to change people's racial attitudes. Id. 
history of struggle to attain acknowledgment of African-American humanity, yet Loury suggests that this presumption of humanity is not only rarely given, but has yet to occur with respect to African Americans despite these efforts. Affirmative action and similar "tax and transfer" strategies may resolve certain aspects of structural inequality, but it is not entirely clear that this will also eliminate racial stigma of the sort identified by Loury. There is little guidance to be drawn from Loury's meditation on the shape of ideal structural reform. Symbolic efforts, such as hate crime legislation, ${ }^{109}$ express the view that all are entitled to a presumption of humanity. ${ }^{110}$ Perhaps this is the path to reform that Loury has in mind.

While Loury's argument employs the rhetoric of optimism, its logic indulges the nihilistic impulse to slip into despair. The conundrum of racial stigma brings to mind the blunt observations of Charles Cooley that " $\mathrm{t}] \mathrm{wo}$ races of different temperament and capacity, distinct to the eye and living side by side in the same community, tend strongly to become castes, no matter how equal the social system may be" 111 or the painful observations of James Baldwin that "[i]t is exceedingly difficult for most of us to discard the assumptions of the society in which we were born, in which we live, to which we owe our identities; . . . virtually impossible, if not completely impossible, to envision the future, except in those terms which we think we already know." 112 Loury asks us to contest this proposition with all our moral

\footnotetext{
109 For a comprehensive discussion of hate crime legislation, see FREDERICK M. LAWRENCE, Punishing Hate: Bias Crimes Under American LaW (1999). For a critical perspective on hate crime legislation, see James B. Jacobs \& Kimberly Potter, Hate Crimes: Criminal LaW \& IDENTITY POLITICS (1998).

110 See LAWRENCE, supra note 109, at 103. As Lawrence explains:

It is not necessary to prohibit either all fighting words or none ... [A] state may properly make the judgment that, within the universe of assaults, some are worse than others. For instance, an assault with a deadly weapon is, in most states, some form of aggravated assault. The crime is more serious than unarmed assault because the defendant has exposed society to greater risk - even if the weapon is not actually used - and has presumably caused greater fear in the victim .... Similarly, a state may determine that assaults [or threats to assault] based on race are worse than comparable assaults [or threats], because these racially motivated assaults cause greater societal harm and injury to the individual and community victims.

Id. There is a vast literature on the expressive function of the law. See, e.g., Elizabeth S. Anderson \& Richard H. Pildes, Expressive Theories of Law: A General Restatement, 148 U. PA. L. REV. 1503 (2000); Robert Cooter, Do Good Laws Make Good Citizens? An Economic Analysis of Internalized Norms, 86 VA. L. ReV. 1577 (2000); Richard H. McAdams, A Focal Point Theory of Expressive Law, 86 VA. L. REV. 1649 (2000); Robert Cooter, Expressive Law and Economics, 27 J. LEGAL STUD. 585 (1998); Paul H. Robinson \& John M. Darley, The Utility of Desert, 91 Nw. U. L. ReV. 453, 471-73 (1997); Cass R. Sunstein, On the Expressive Function of Law, 144 U. PA. L. REV. 2021, 2022 (1996); Dan M. Kahan, What Do Alternative Sanctions Mean?, 63 U. CHI. L. REv. 591, 597 (1996); Lawrence Lessig, The Regulation of Social Meaning, 62 U. CHI. L. Rev. 943 (1995); Richard H. Pildes, Why Rights Are Not Trumps: Social Meanings, Expressive Harms, and Constitutionalism, 27 J. LegaL STUD. 725 (1998).

111 Charles Cooley, Social Organization: A Study of the Larger Mind 215 (1909).

112 James Baldwin, Every Goodbye Ain't Gone, in The Price of the Ticket: COllected NONFICTION 643 (1985) (emphasis added).
} 
might. Yet the persistence of racial disparities serves as a chronic source of frustration for racial progressives.

In my own view, there is no elegant solution to the race problem in America. Contemporary notions of race and racial identity carry forward the heavy baggage of centuries of devastating racial oppression. This devastation was premised upon an enduring belief in the salience of the racial divide. But race has not always had catastrophic meaning in the lives of non-whites. Voluntary segregation in residential patterns, church affiliation, and club membership hint at an enduring feature of American lifethat persons of all races frequently find comfort and solace in racially segregated private space. Race matters today and will matter in the foreseeable future precisely because race mattered so much in the past and so much of ourselves continues to ride on racial ancestry. Our race consciousness is as much a trap of circumstance as it is a web of safety.

For this reason, I am inclined to reject the elegant formulation of the colorblind ideal and its deep skepticism regarding the deployment of racial classifications. The more compelling approach to racial justice is one that is sufficiently nuanced to attack vigorously the more pernicious applications of race that perpetuate racial inequality without sacrificing the virtues of racial identity and the sanctuary that group affiliation provides. I have always believed that the ultimate basis by which the achievements of American democracy should be judged is its ability to confront and respond meaningfully to the absurdity of race and racial injustice. To understand today's racial disparities, one must first come to terms with the horrific absurdity of America's racial past and its intended consequence - the strategic underdevelopment of certain racial communities.

An elegant legal response to remedy the effects of generations of brute racism is arguably desirable, but by no means necessary. Professor Stanely Fish's response to the claim that affirmative action constitutes "reverse racism" is particularly illuminating on this point:

Reverse Racism is a cogent description of affirmative action only if one considers the cancer of racism to be morally and medically indistinguishable from the therapy we apply to it. A cancer is an invasion of the body's equilibrium, and so is chemotherapy; but we do not decline to fight the disease because the medicine we employ is also disruptive of normal functioning. Strong illness, strong remedy: the formula is as appropriate to the health of the body politic as it is to that of the body proper." 113

Perhaps it is best to turn our attention away from the question of how to eliminate racial stigma in the minds and hearts of Americans, and toward the more immediate, constructive (and arguably radical) enterprise of how to deepen and evolve our legal theory so that our institutions can begin to

\footnotetext{
113 Stanley Fish, Reverse Racism or How the Pot Got To Call the Kettle Black, ATLANTIC MONTHLY, Nov. 1993, at 128, 130.
} 
address the current state of material and social inequity correlated to race in an unapologetically race-conscious manner.

Since the beginning of the nation, white Americans have suffered from a deep inner uncertainty as to who they really are. One of the ways that has been used to simplify the answer has been to seize upon the presence of black Americans and use them as a marker, a symbol of limits, a metaphor for the "outsider." The Anatomy of Racial Inequality offers a provocative look at the manner in which race and the attribution of "outsider status" contributes to the social and economic isolation of African Americans. Loury reminds us that this "outsider status"-past and present-has real consequences in terms of the underdevelopment of African Americans in social, political, and economic life. Loury's moving text is a clarion call to each of us to shake our indifference and respond meaningfully to this crisis. In this sense, Loury is not unlike Gunnar Myrdal, who argued that justice and equality for African Americans was not simply a moral duty, but part of living up to the "American Creed." 114 And like Myrdal, Loury's words inspire us to challenge prevailing attitudes regarding racial difference, and boldly embrace a more promising, egalitarian vision as we contemplate the shape of the nation to come.

\footnotetext{
114 See Gunnar Myrdal, An American Dilemma: The Negro Problem and Modern DEMOCRACY 3-26 (1944) (discussing features of the "American Creed" and its relationship to the status of African Americans in public life).
} 
N ORT H W ESTER N UN IVER S T Y L A W R E VIE W 